\title{
Roles for proteinases in the pathogenesis of chronic obstructive pulmonary disease
}

\author{
Caroline A Owen \\ Division of Pulmonary and Critical \\ Care Medicine, Brigham and Women's \\ Hospital and Harvard Medical School, \\ Boston, MA, USA
}

\begin{abstract}
Since the early 1960s, a compelling body of evidence has accumulated to show that proteinases play critical roles in airspace enlargement in chronic obstructive pulmonary disease (COPD). However, until recently the causative enzymes and their exact roles in pathologic processes in COPD have not been clear. Recent studies of gene-targeted mice in murine models of COPD have confirmed roles for proteinases not only in airspace enlargement, but also in airway pathologies in COPD. These studies have also shed light on the specific proteinases involved in COPD pathogenesis, and the mechanisms by which these proteinases injure the lung. They have also identified important interactions between different classes of proteinases, and between proteinases and other molecules that amplify lung inflammation and injury. This review will discuss the biology of proteinases and the mechanisms by which they contribute to the pathogenesis of COPD. In addition, I will discuss the potential of proteinase inhibitors and anti-inflammatory drugs as new treatment strategies for COPD patients.
\end{abstract}

Keywords: proteinase, proteinase inhibitor, proteolysis, chronic obstructive pulmonary disease, inflammation, mucus hypersecretion

\section{Introduction}

COPD is currently the fourth most common cause of death in the USA, and its incidence is increasing, especially in women, worldwide and in third-world countries. The National Heart, Lung, and Blood Institute has estimated the annual costs of COPD in the USA in 2005 to be US\$38.8 billion. COPD is the least well-funded disease relative to its global heath burden. As a result of the huge healthcare burden associated with COPD, there has been a resurgence of interest in its cellular and molecular mechanisms, and in the development of new treatment strategies to limit the deleterious effects of proteinases in the lungs of COPD patients.

\section{Pathology}

In developed countries, the main risk factor for COPD is smoking cigarettes, which accounts for more than $95 \%$ of all cases. Other risk factors include inhalation of pollutants, wood smoke, and biomass fuels in enclosed spaces in third-world countries. Genetic factors may also increase individual susceptibility to the adverse effects of cigarette smoke, or alter normal lung repair processes. Inhalation of cigarette smoke and other pollutants leads to a chronic inflammatory process in the small airways and the lung parenchyma including macrophages, polymorphonuclear neutrophils (PMN), $\mathrm{T}$ lymphocytes (with CD8+ T cells exceeding the numbers of CD4+ T cells), and B lymphocytes (Di Stefano et al 1996; Saetta 1999; Turato et al 2001; Hogg et al 2004). Over time, there is destruction of the alveolar walls leading to airspace enlargement, loss of lung elasticity, closure of small airways, and irreversible airflow obstruction. Pathological changes also develop in the airways, including mucus metaplasia and mucus hyper-secretion. Narrowing of the small airways develops as a result of mucus 
plugging, inflammation in the airway walls and lumen, and subepithelial fibrosis. This small airway obstruction is also an important determinant of the fixed airflow obstruction that occurs in COPD patients (Hogg et al 2004). Although COPD is a complex disorder caused by multiple mediators and pathways (including reactive oxygen species [ROS], pro-inflammatory mediators, apoptosis of structural cells, and inadequate repair processes), there is strong evidence that proteinases make critical contributions to all the pathologic processes detected in the lungs of COPD patients.

\section{Historical aspects of proteinases in COPD: The proteinase- antiproteinase hypothesis}

Two observations in the 1960s, one clinical and one experimental, led to the proteinase/antiproteinase hypothesis for the pathogenesis of emphysema. The first observation was that genetic deficiency of $\alpha_{1}$-proteinase inhibitor $\left(\left[\alpha_{1}-\mathrm{PI}\right]\right.$, which is the major inhibitor of neutrophil elastase $[\mathrm{NE}]$ in the lower respiratory tract) is associated with early-onset, severe panlobular pulmonary emphysema (Laurell and Eriksson 1963). The second observation was that instillation of papain (a metalloproteinase with elastin-degrading activity) into rat lungs results in progressive airspace enlargement (Gross et al 1965). Since then, other proteinases that degrade lung elastin, including porcine pancreatic elastase (Karlinsky et al 1983) and subsequently NE and proteinase 3 (PR3), which are more relevant to human COPD compared to porcine pancreatic elastase, were shown to enlarge airspaces when instilled into the lungs of experimental animals (Senior et al 1977; Kao et al 1988). Based upon these observations the proteinase-anti-proteinase hypothesis was formulated: Inhalation of cigarette smoke (or other pollutants) leads to the recruitment of inflammatory cells into the lungs. Inflammatory cells release various proteinases that exceed the proteinase inhibitor defense of the lung. Uncontrolled proteinases degrade the extracellular matrix (ECM) protein components of the alveolar walls (especially the elastic fibers) leading to destruction and loss of the alveolar walls and airspace enlargement (Figure 1).

Because of the association between $\alpha_{1}$-PI deficiency and pulmonary emphysema, early studies focused on the role of NE in airspace enlargement. While unrestrained NE activity in the lung is likely to be important in the panlobular pulmonary emphysema associated with $\alpha_{1}$-PI deficiency, this is probably an oversimplification of mechanisms underlying the majority of COPD patients, who have normal plasma levels of $\alpha_{1}$-PI. Studies during the last 3-4 decades have identified roles for other proteinases in airspace enlargement, roles for proteinases in airways pathologies (Figure 1), and important interactions between different classes of proteinases and between proteinases and other molecules (eg, ROS and inflammatory mediators) that amplify inflammation and ECM destruction in COPD.

\section{Classification and biology of proteinases}

Proteinases cleave the internal peptide bonds of polypeptides. They can be classified into 4 groups by the chemical nature of their active site: serine, metallo-, cysteine, and aspartic proteinases (Table 1). Proteinase inhibitors are generally targeted against individual classes of proteinases (Table 1). Serine proteinases and MMPs are optimally active at neutral $\mathrm{pH}$ and have the largest role in extracellular proteolysis. Cysteine and aspartic proteinases are optimally active at acidic $\mathrm{pH}$, and their main role is in intracellular degradation of proteins in lysosomes. However, acid proteinases can degrade extracellular proteins if they retain catalytic activity at neutral $\mathrm{pH}$ or are released into an environment having an acidic $\mathrm{pH}$, such as the pericellular environment of activated macrophages (Mason et al 1986; Shi et al 1992). The proteinases implicated in the pathogenesis of COPD belong to the serine, metallo-, and cysteine proteinase classes.

\section{Serine proteinases}

Serine proteinases implicated in COPD include PMN-derived serine proteinases, urokinase-type plasminogen activator (uPA), granzymes, and plasmin (Table 1).

\section{PMN-derived serine proteinases}

These include NE, PR3, and cathepsin G (CG). PMN and pro-inflammatory monocytes store preformed serine proteinases in their primary granules, from which the enzymes are released when pro-inflammatory mediators induce PMN degranulation (Owen et al 1994; Owen and Campbell 1999). Together, these serine proteinases have a broad spectrum of activity against ECM proteins (especially elastin) and nonECM proteins (Owen and Campbell 1999).

\section{Urokinase-type plasminogen activator (uPA)}

This enzyme is expressed by PMN, monocytes, and macrophages. Preformed uPA is stored in and released from the specific granules of PMN. However, uPA expression is regulated at the transcriptional level in mononuclear phagocytes by pro-inflammatory mediators (Granelli-Peperno et al 1977; Vassalli et al 1991). Following its release from cells, uPA binds 


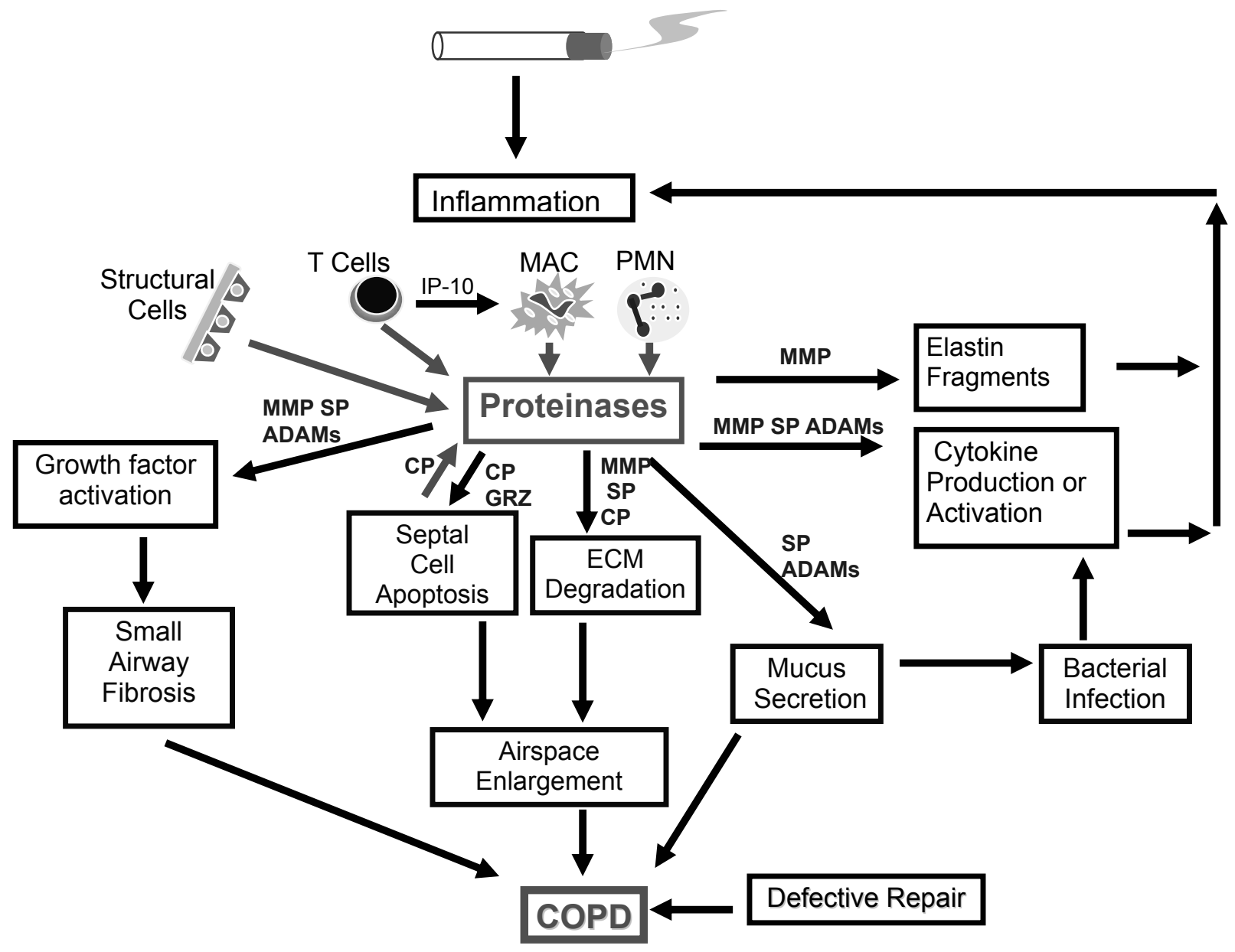

Figure I Mechanisms by which different classes of proteinases contribute to pathologies in COPD. Cigarette smoke stimulates inflammatory cell recruitment, proteinase production, and proteinase release from inflammatory, immune, and structural cells in the lung. Proteinases contribute to airspace enlargement by degrading ECM and promoting death of structural cells of the alveolar walls. Proteinases also amplify lung inflammation and promote mucus hypersecretion and small airway fibrosis.

Abbreviations: COPD, chronic obstructive pulmonary disease; ECM, extracellular matrix; MAC, macrophages; PMN, polymorphonuclear neutrophils; IP-I0, interferon- $\gamma$ -inducible protein-10; SP, serine proteinases; MMP, matrix metalloproteinases;ADAMs, proteinases with a disintegrin and a metalloproteinase domain; CP, cysteine proteinases; GRZ, granzymes.

to a specific receptor (uPA receptor) on phagocyte surfaces, where it functions as a cell-associated proteinase. The main function of uPA is to convert inactive plasminogen to active plasmin, another serine proteinase. Plasmin degrades fibrin during lysis of blood clots. However, plasmin also cleaves and activates latent growth factors, latent proMMPs, and proteaseactivated receptor-1 (PAR-1) on macrophages, which drives macrophage MMP-12 production (Saksela and Rifkin 1988; Taipale et al 1992; Raza et al 2000; Churg et al 2007b). Thus by generating plasmin, uPA regulates not only fibrinolysis, but also ECM degradation and fibrotic processes in the lung.

\section{Granzymes (GRZ)}

Granzymes are granule-associated enzymes that are predominantly expressed by CD8+ T lymphocytes and are stored in the lytic granules of these cells (Smyth et al 1996).
The main GRZ family members in human CD8+ T cells are GRZ A and B. Activation of CD8+ T cells by antigen leads to rapid exocytosis of GRZ and perforin-containing granules. Perforin alters the properties of the cell membrane of the target cells, allowing entry of GRZ into the target cell, and GRZ A and GRZ B then initiate caspase-independent and caspase-dependent apoptosis, respectively.

\section{Serine proteinase inhibitors}

Serine proteinase inhibitors in plasma and interstitial fluids include $\alpha_{1}$-PI, $\alpha_{1}$-antichymotrypsin, plasminogen activator inhibitors, $\alpha_{2}$-plasmin inhibitor, and the universal inhibitor, $\alpha_{2}$-macroglobulin $\left(\alpha_{2}-\mathrm{M}\right)$, which inhibits all four classes of enzymes (Carrell 1986). Secretory leukocyte proteinase inhibitor (SLPI) and elafin are synthesized locally in the respiratory tract by epithelial cells. 
Table I Proteinases involved in the pathogenesis of COPD

\begin{tabular}{|c|c|c|c|c|}
\hline $\begin{array}{l}\text { Class of } \\
\text { proteinase }\end{array}$ & $\begin{array}{l}\text { Optimum } \\
\text { pH }\end{array}$ & Examples & Sources & Inhibitors \\
\hline \multirow{7}{*}{$\begin{array}{l}\text { Serine } \\
\text { proteinases }\end{array}$} & & Neutrophil elastase (NE) & PMN & $\alpha_{1}$-proteinase inhibitor $\left(\alpha_{1}-\mathrm{Pl}\right)$ \\
\hline & & Cathepsin G (CG) & P Monocytes & $\alpha_{1}$-antichymotrypsin $\left(\alpha_{1}-\right.$ Ach $)$ \\
\hline & & Proteinase 3 (PR3) & & $\begin{array}{l}\text { Secretory leukocyte protease } \\
\text { inhibitor (SLPI) Elafin } \\
\alpha_{2} \text {-macroglobulin }\left(\alpha_{2} M\right)\end{array}$ \\
\hline & Neutral & $\begin{array}{l}\text { Urokinase-type plasminogen } \\
\text { Activator (uPA) }\end{array}$ & PMN, monocytes, macrophages & $\begin{array}{l}\text { Plasminogen activator inhibi- } \\
\text { tors (PAI) }\end{array}$ \\
\hline & & Granzymes & CD8+T cells, NK cells & Not known \\
\hline & & Thrombin & Plasma & Anti-thrombin III, $\alpha_{1}-\mathrm{PI}$ \\
\hline & & Plasmin & Plasminogen in plasma & $\alpha_{2}$-antiplasmin, $\alpha_{1}-\mathrm{PI}$ \\
\hline \multirow{4}{*}{$\begin{array}{l}\text { Metallo- } \\
\text { proteinases }\end{array}$} & Neutral & Matrix metalloproteinases & Granulocytes & Tissue inhibitor of metallo- \\
\hline & & (MMP) ADAMs & Monocytes and Macrophages & proteinases \\
\hline & & & Epithelial cells & (TIMPs- I-4) \\
\hline & & & Fibroblasts & $\alpha$-macroglobulin \\
\hline Cysteine & Acidic & Cathepsins B, S, H, L & Inflammatory cells & Cystatins A, C, S \\
\hline \multirow[t]{5}{*}{ proteinases } & & Caspases & T cells & $\alpha_{2}$-macroglobulin \\
\hline & & & Epithelial cells & Kininogens \\
\hline & & & Inflammatory cells & Inhibitors of apoptosis pro- \\
\hline & & & Endothelial cells & teins (IAPs) \\
\hline & & & Epithelial cells & $\mathrm{CmrA}, \mathrm{p} 35, \alpha_{1}-\mathrm{PI}$ \\
\hline
\end{tabular}

Abbreviations: COPD, chronic obstructive pulmonary disease; PMN, polymorphonuclear neutrophils; ADAMs, proteinases containing a disintegrin and a metalloproteinase domain; P-monocytes, pro-inflammatory monocytes.

\section{Metalloproteinases}

This class of proteinases includes the matrix metalloproteinases (MMPs) and members of the ADAMs family.

\section{MMPs}

MMPs have an $\mathrm{NH}_{2}$ terminal pro domain, an active site zinc atom, and a $\mathrm{COOH}$ terminal hemopexin domain that regulates the binding of the enzymes to their substrates. MMPs are generally produced as inactive proenzymes (proMMPs). Latency is maintained by an interaction between the active site zinc atom and a conserved cysteine residue in the pro domain. Activation of proMMPs occurs when this interaction is disrupted, which may be achieved by the actions of other proteinases and oxidants in the extracellular space (the cysteine switch mechanism of activation of proMMPs [Murphy et al 1999; Fu et al 2001]). Some MMPs are activated in the transgolgi by cleavage of the prodomain by furin, an intracellular serine proteinase (Imai et al 1996; Cao et al 2005). MMPs are generally synthesized de novo by cells activated by pro-inflammatory mediators or growth factors. However, PMN store preformed MMP-8, MMP-9, and MT6-MMP (MMP-25) in their cytoplasmic granules, from which the enzymes are released when PMN degranulate (Owen and Campbell 1999). Macrophages express MMPs-1, -3, -7, -9, -12, and -14 (Shapiro et al 1991; Rajavashisth et al 1999), and lung epithelial cells and fibroblasts produce MMPs-2, -9 , and 14. MMPs are subdivided into 6 groups based upon a similar domain organization and substrate specificity including: 1) the interstitial collagenases (MMPs-1, -8 , and -13); 2) the gelatinases (MMPs-2 and -9); 3) the stromelysins (MMPs-3, -10, and -11); 4) matrilysin (MMP-7); 5) metalloelastase (MMP-12); and 6) membrane-type MMPs (MT-MMPs), which are integral membrane proteinases having either a transmembrane domain or a glycosylphosphatidyl-inositol anchor to the cell membrane (Sato et al 1994; Takino et al 1995). The interstitial collagenases degrade interstitial collagens. The other subgroups have broader substrate specificities including denatured collagens (gelatins), basement membrane proteins, and pro-inflammatory mediators. MMPs-7, -9, and -12 also degrade elastin (Owen and Campbell 1999).

\section{ADAM}

ADAMs are a family of type I transmembrane proteinases, so called because they contain a disintegrin and a metalloproteinase domain (Primakoff and Myles 2000). The metalloproteinase domain of ADAMs sheds membrane-anchored cytokines such as pro-tumor necrosis factor (TNF- $\alpha$ ), other cytokines, growth factors, apoptosis 
ligands and receptors for these molecules from cell surfaces to regulate inflammation, apoptosis, and possibly fibrotic processes (Black et al 1997; Primakoff and Myles 2000; Black 2002). The disintegrin domain binds to integrins to regulate integrin-mediated cell adhesion and migration (Primakoff and Myles 2000).

MMPs are inhibited by $\alpha_{2}-\mathrm{M}$ and the four members of the tissue inhibitors of metalloproteinases family (TIMPs1-4), which are synthesized by connective tissue cells and leukocytes and form non-covalent complexes with MMPs (Woessner Jr 1991; Murphy and Docherty 1992). The inhibitors of ADAMs have not been fully elucidated, but ADAM-17 is inhibited by TIMP-3 but not TIMP-1 or -2 (Amour et al 1998; Black 2004).

\section{Cysteine proteinases}

Cathepsins B, H, L, and S have been implicated in COPD (Table 1). Cathepsin S and L are potent elastases in vitro (Mason et al 1986; Shi et al 1992) and contribute to macrophage-mediated ECM degradation. The main inhibitors of cysteine proteinases are the cystatin superfamily, the kininogens, and $\alpha_{2}-\mathrm{M}$ (Henskens et al 1996).

\section{Roles of proteinases in COPD}

Evidence for roles of proteinases in COPD comes from studies of purified proteinases, studies of clinical samples from COPD patients, and animal models of COPD.

\section{In vitro studies of proteinases}

Lung inflammation and airspace enlargement

$\mathrm{NE}, \mathrm{CG}, \mathrm{PR} 3$, and GRZ have the potential to promote lung inflammation in COPD patients, because they stimulate the release of pro-inflammatory mediators from airway epithelial cells and macrophages in vitro (Hubbard et al 1991; Bedard et al 1993). Proteinases can also proteolytically cleave mediators to alter their biologic activities (Figure 1). MMPs-8 and -9 cleave and activate various chemokines in vitro (Van Den Steen et al 2000; Balbin et al 2003). ADAM-17 and several MMPs shed and activate membrane-associated pro-TNF- $\alpha$ from macrophage surfaces (Primakoff and Myles 2000; Black 2002; Churg et al 2003a). NE, MMP-12, and MMP-9 cleave elastin, and MMPs cleave $\alpha_{1}$-PI, generating fragments of these two molecules that are chemotactic for inflammatory cells (Senior et al 1980; Hunninghake et al 1981). Serine, metallo-, and cysteine proteinases acting together can degrade elastin, interstitial collagens, and basement membrane proteins in vitro (Owen and Campbell 1999). All of these ECM proteins must be degraded when lung airspaces enlarge (Figure 1).

\section{Airway pathologies}

NE, MMP-9, and ADAMs-10 and -17 increase epithelial cell expression of MUC5AC, a major mucin protein, by activating epithelial growth factor receptor (EGFR) through shedding of membrane - bound pro-transforming growth factor (TGF)- $\alpha$. This releases soluble, active TGF- $\alpha$, which activates the EGFR (Kohri et al 2002; Shao et al 2004; Deshmukh et al 2005). NE, CG, and PR3 potently stimulate goblet cell degranulation (Sommerhoff et al 1990). Tissue kallikrein is a serine proteinase expressed by inflammatory cells and submucosal glands. It also stimulates mucin synthesis in airway epithelium in vitro by shedding and activating pro-EGF, another EGFR ligand (Casalino-Matsuda et al 2006). NE also damages epithelial cells (Amitani et al 1991) and inhibits ciliary beat frequency of lung epithelial cells (Smallman et al 1984). Increased production and impaired clearance of mucus predispose COPD patients to recurrent bacterial airway infections, which amplify airway inflammation and injury (Figure 1).

Plasmin, MMP-9, NE, and ADAMs may also induce subepithelial fibrosis in COPD airways, because they activate latent growth factors such as TGF- $\beta$ (Taipale et al 1992; $\mathrm{Yu}$ and Stamenkovic 2000; Chua et al 2007) and insulinlike growth factors in vitro (Fowlkes et al 1999; Mohan et al 2002) and these growth factors induce fibroblasts to synthesize and secrete interstitial collagens. However, it has not been determined whether these proteinases induce sub-epithelial fibrosis in the small airways of human COPD patients.

\section{Studies of clinical samples from human COPD patients}

In addition to the early observation that $\alpha_{1}$-PI-deficient patients have early-onset emphysema, elegant studies from Damiano and colleagues (1986) further supported a role for NE in pulmonary emphysema. They localized NE bound to lung elastic fibers and showed that the amount of NE bound to lung elastin is strongly correlated with the degree of emphysematous change. Since then, additional studies have confirmed increased levels of NE in lung samples from COPD patients and demonstrated elevated levels of CG, PR3, uPA, and MMPs -1, -2, -8, -9, and -14 in various lung samples from smokers and COPD patients when compared with healthy subjects (Damiano et al 1986; Reilly and Chapman Jr 1988; Abboud et al 1998; Betsuyaku et al 1996; Finlay et al 1997; Betsuyaku et al 1999; Hill et al 1999; Betsuyaku et al 2000b; Cataldo et al 2000; Imai et al 2001; Beeh et al 2003; Kang et al 2003). 
Although most studies have implicated proteinases from inflammatory cells in COPD pathogenesis, proteinases produced by lung structural cells and immune cells also play important roles (Figure 1). For example, cigarette smoke increases MMP production by lung epithelial cells (Imai et al 2001), and fibroblasts (Ning et al 2007). T lymphocytes from blood and BAL samples from COPD patients have increased levels of GRZ and perforin compared to samples from asymptomatic smokers and nonsmokers (Hodge et al 2006). Elevated levels of GRZ B in BAL samples from COPD patients are correlated with bronchial epithelial cell apoptosis, suggesting that GRZ B promotes epithelial cell death in the lung and contributes to airspace enlargement in COPD patients (Figure 1).

\section{Animal models of COPD}

Animal models of COPD provide the strongest evidence for the roles of proteinases in COPD.

\section{Acute cigarette smoke exposure models}

Acute exposure of mice to cigarette smoke for up for 30 days results in increases in lung PMN and macrophages and breakdown of lung collagen and elastin (Churg et al 2002). Studies of mice genetically deficient in proteinases in these acute exposure models have identified critical roles for MMP-12 in regulating PMN influx and for thrombin and plasmin in regulating MMP-12 production (Figure 2). Cigarette smoke acutely upregulates macrophage MMP-12 levels by injuring lung capillaries (Burns et al 1989; Li et al 1996), leading to leakage of thrombin and plasmin into the alveolar space. Thrombin and plasmin cleave, thereby activating proteaseactivated receptor -1 (PAR-1) on macrophages. Signaling through PAR-1 increases macrophage MMP-12 synthesis (Raza et al 2000; Churg et al 2007b). Macrophage-derived MMP-12 regulates PMN influx into the lung by shedding pro-TNF- $\alpha$ from activated macrophages, which likely upregulates E-selectin expression on endothelial cells to promote PMN transendothelial migration (Churg et al 2003a) and lung ECM degradation by PMN-derived serine proteinases (Figure 2). It is noteworthy that delivering human $\alpha_{1}$-PI to mice acutely exposed to cigarette smoke prevents PMN influx and ECM destruction. This is probably due to $\alpha_{1}$-PI inhibiting both PMN serine proteinase-mediated ECM destruction and thrombin- or plasmin-induced increases in macrophage MMP-12 production (Churg et al 2003b, 2007b).

\section{Chronic smoke exposure models}

Exposure of WT mice to cigarette smoke for 3-6 months results in airspace enlargement, inflammation, and subepithelial fibrosis in the small airways, similar to that reported in human cigarette smokers (Hautamaki et al 1997; Martin et al 2001). Studies of proteinase-deficient mice in this model have confirmed roles for MMP-12 and NE in regulating chronic lung inflammation and airspace enlargement (Figure 3) and for MMP-9 and/or MMP-12 in inducing subepithelial fibrosis in the small airways of smoke-exposed mice.

Mice deficient in MMP-12 (MMP-12-/- mice) exposed to cigarette smoke for 6 months are completely protected from developing increased lung macrophage counts and from developing airspace enlargement (Hautamaki et al 1997). MMP-12 degrades elastin and other ECM components to cause airspace enlargement (Figure 3 ). The decreased macrophage accumulation in MMP- $12^{-/-}$mice is due to the lack of MMP-12-mediated cleavage of elastin, which generates elastin fragments that are chemotactic for blood monocytes (Figure 3) (Houghton et al 2006b). T lymphocyte products also play a critical role in driving MMP-12-mediated inflammation and airspace enlargement, since CD8+ T-cell-deficient ( $\left.\mathrm{CD}^{-/-}\right)$mice have a blunted inflammatory response to cigarette smoke and fail to develop emphysema (Maeno et al 2007). This is mediated by a CD8+ T cell product, IFN- $\gamma$ inducible protein 10 (IP-10), which induces production of MMP-12 and degradation of the lung ECM (Figures 1 and 3). This process may also contribute to COPD pathogenesis in human subjects, since lung tissue from human COPD patients contains increased numbers of Th1 cells associated with increased levels of IP-10 and MMP-12 (Grumelli et al 2004).

$\mathrm{NE}^{-/-}$mice are $60 \%$ protected from airspace enlargement and have decreased influx of PMN and monocytes into the lung compared to smoke-exposed WT mice (Shapiro et al 2003) (Figure 3). NE likely contributes to airspace enlargement directly by degrading elastin and other ECM protein components of the alveolar walls (Shapiro et al 2003) (Figure 3), but the mechanisms by which NE promotes lung inflammation are not clear.

When rodent airways are exposed acutely to cigarette smoke, increases in growth factor and collagen production are detectable within $2 \mathrm{~h}$, and before inflammation occurs in the airway walls (Churg et al 2006). This indicates that smoke directly promotes small airway subepithelial fibrosis and that smoke-induced inflammation and proteinase production are unnecessary for this process. However, in guinea pigs chronically exposed to cigarette smoke for up to 6 months, inflammatory cell MMPs amplify this process, since delivering a synthetic dual inhibitor of MMPs-9 and -12 


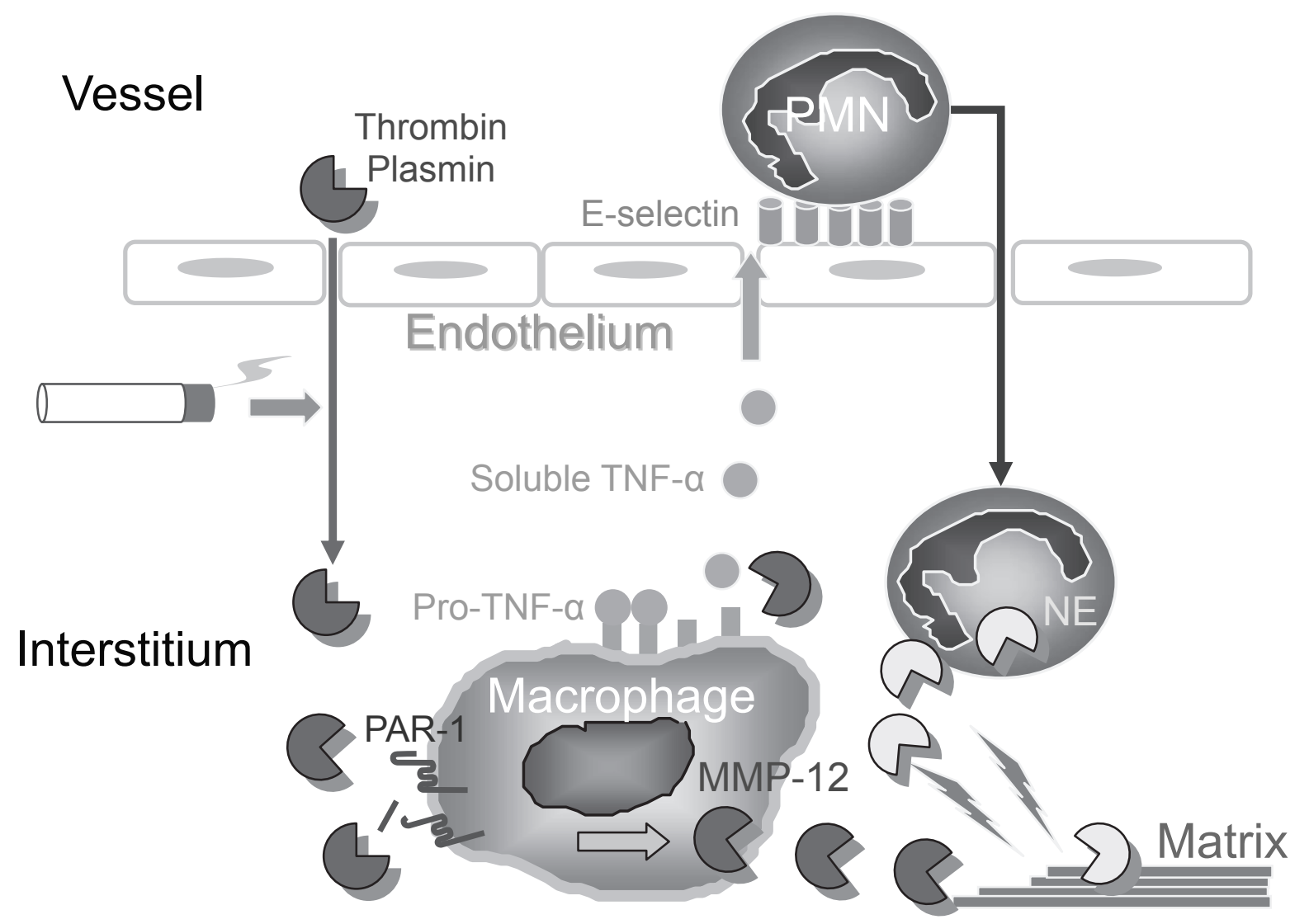

Figure 2 Interactions between proteinases regulate inflammation and matrix destruction in mice acutely exposed to cigarette smoke. Cigarette smoke drives macrophage MMP- 12 production, at least in part by inducing thrombin- and plasmin-mediated activation of protease-activated receptor-I (PAR-I) on macrophages. MMP-12 stimulates PMN accumulation in the lung by shedding pro-TNF- $\alpha$ from the macrophage surface, generating soluble, active TNF- $\alpha$. Active TNF- $\alpha$ stimulates PMN trans-endothelial migration by up-regulating endothelial E selectin expression. PMN proteinases, such as neutrophil elastase (NE), amplify macrophage MMP-12 mediated destruction of the lung ECM.

to these animals significantly reduces small airway fibrosis (Churg et al 2007a). Studies of MMP inhibitors in human COPD patients are thus warranted to determine whether these proteinases play important roles in this important pathology in humans as well as mice.

\section{Transgenic murine models}

Transgenic mice over-expressing MMP-1 in the lung develop enlarged airspaces (D'Armiento et al 1992), which may either reflect abnormal alveolar development or destruction of mature interstitial collagens by MMP-1. Assessment of transgenic mice inducibly over-expressing cytokines in the adult lung have confirmed a role for immune-mediated inflammation in airspace enlargement. Adult transgenic mice over-expressing a Th1 cytokine (IFN- $\gamma$ ), a Th2 cytokine (IL-13), or a cytokine with Th1 and Th2 activities (IL-18) in airway epithelial cells spontaneously develop striking lung inflammation, increased lung levels of MMPs and cysteine proteinases, and airspace enlargement (Wang et al 2000; Zheng et al 2000; Kang et al 2007). In mice over-expressing
IL-13, MMPs -9 and -12 play critical roles in promoting airspace enlargement, and MMP-12 also promotes inflammation and drives the increased expression of other MMPs in the lung (Lanone et al 2002). In transgenic mice overexpressing IFN- $\gamma$, cathepsin S stimulates lung epithelial apoptosis, lung inflammation, and airspace enlargement (Zheng et al 2005).

\section{Alveolar septal cell apoptosis models of airspace enlargement}

Apoptosis of alveolar septal cells (Aoshiba et al 2001) and leukocytes (Aoshiba et al 2001; Hodge et al 2005) occurs in the lungs of COPD patients, and apoptosis of the endothelial and epithelial cells that make up the alveolar walls contributes to the development of emphysema. Septal cell apoptosis and airspace enlargement in the absence of overt lung inflammation can be induced rapidly in experimental animals by: 1) pharmacologic blockade of vascular endothelial growth factor receptors in rodents (Kasahara et al 2000); and 2) transfection of murine alveolar epithelial cells with caspase-3, a pro-apoptotic 


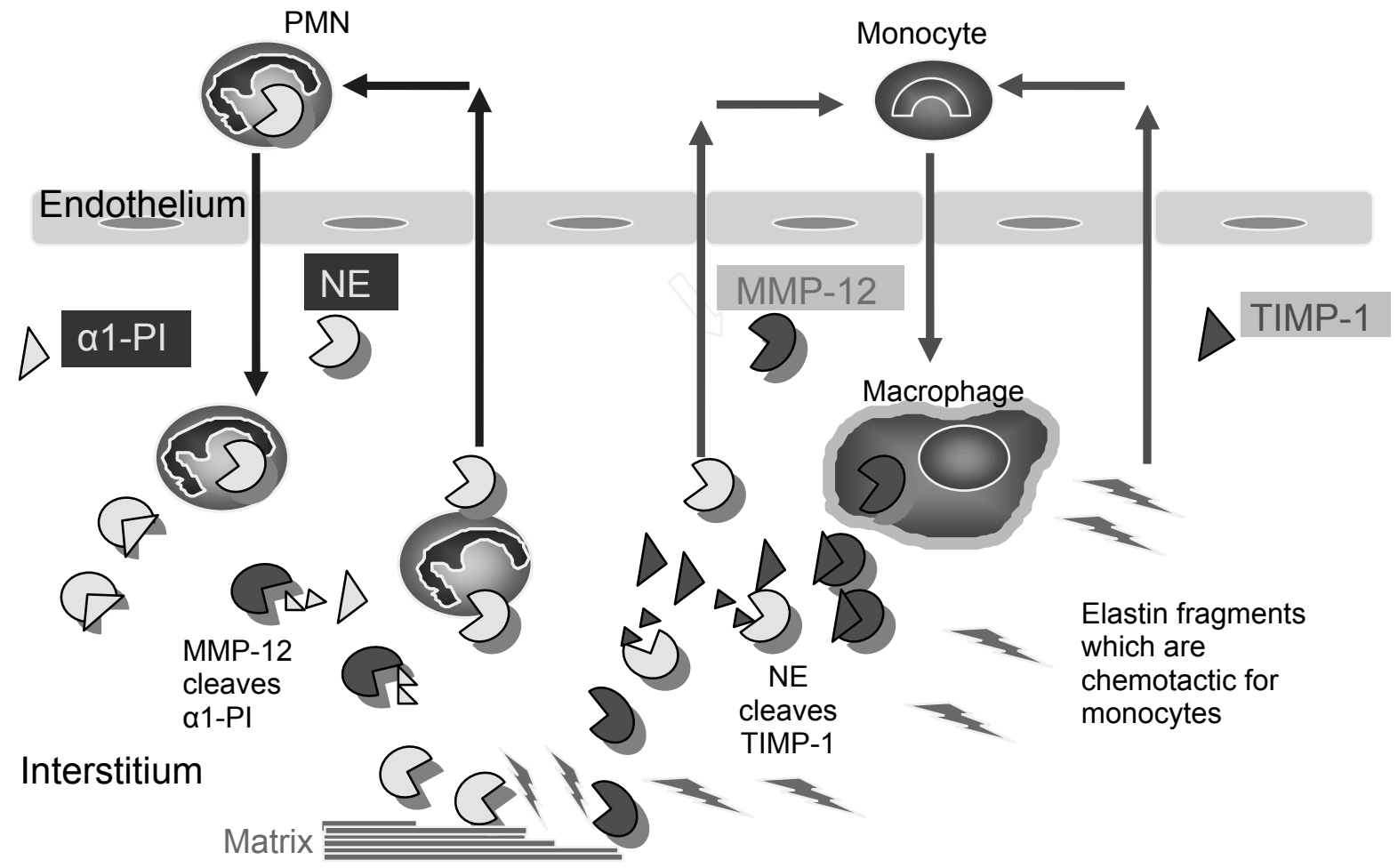

Figure 3 Interactions between proteinases regulate inflammation and ECM destruction in mice chronically exposed to cigarette smoke. Neutrophil elastase (NE) promotes inflammation and ECM destruction in mice chronically exposed to cigarette smoke by increasing the influx of PMN and monocytes into the lung (by unknown mechanisms), and by cleaving and inactivating TIMPs to promote MMP-I 2 mediated ECM degradation. MMP-I 2 amplifies NE-mediated lung inflammation and destruction by cleaving and inactivating $\alpha_{1}-\mathrm{PI}$, the major inhibitor of NE in the lower respiratory tract. Fragments of elastin generated by MMP-I2 (and possibly by NE) amplify MMP-I2-mediated lung injury by stimulating the recruitment of blood monocytes into the lung.

cysteine proteinase (Aoshiba et al 2003). However, increased elastase activity due to acidic proteinase(s) is detected in BAL samples after transfection of alveolar epithelial cells with caspase-3 (Aoshiba et al 2003). Thus, proteinases released from dying structural cells may degrade the lung ECM, thereby acting synergistically with septal cell apoptosis to cause loss of alveolar units and airspace enlargement (Figure 1).

\section{Interactions between proteinases and other mediators and pathways in COPD}

Interactions between different classes of proteinases and between proteinases and other molecules present in COPD lungs either amplify or inhibit proteinase production, lung inflammation, and airspace enlargement in COPD lungs.

Studies of the $\mathrm{NE}^{-/-}$and MMP-12 $2^{-/-}$mice exposed chronically to cigarette smoke demonstrated interactions between these two classes of proteinases (Figure 3), with MMP-12 cleaving and inactivating $\alpha_{1}$-PI to increase NE-mediated lung injury, and NE cleaving and inactivating TIMP-1 to amplify MMP-12-mediated lung destruction (Shapiro et al 2003). Proteinases also interact with ROS present in cigarette smoke itself and are generated by phagocytes activated by cigarette smoke. ROS activate proMMPs in vitro and have been thought to exacerbate lung inflammation and injury in COPD patients (Owen 2005). Consistent with this hypothesis, mice transgenically over-expressing the antioxidant enzyme $\mathrm{Cu}-\mathrm{Zn}$ superoxide dismutase in the lung are protected from developing chronic lung inflammation, increased lung MMP levels, and emphysema in response to intratracheal instillation of porcine pancreatic elastase, or chronic exposure to cigarette smoke (Foronjy et al 2006). However, mice deficient in a phagocyte-specific component of the NADPH oxidase, which generates superoxide anions $\left(\mathrm{O}_{2}^{-}\right)$, develop greater airspace enlargement in response to cigarette smoke than WT mice (Kassim et al 2005). This is due to ROSmediated inactivation of MMPs via oxidative inactivation of residues in the catalytic domain of MMPs (Fu et al 2003a). Thus, phagocyte-derived $\mathrm{O}_{2}^{-}$(and $\mathrm{ROS}$ derived from $\mathrm{O}_{2}^{-}$) in COPD lungs may constrain rather than promote phagocyte MMP-mediated lung injury (Fu et al 2003b; Kassim et al 2005). This may be one reason that clinical trials have failed to demonstrate protective effects of antioxidant supplementation in COPD patients (Rahman and MacNee 1996). 


\section{Molecular mechanisms \\ for proteinase-mediated lung injury in COPD}

In order to contribute to pathologies in COPD, proteinases must overcome the effects of proteinase inhibitors, which are present at micromolar concentrations in extracellular fluids. Proteinases circumvent the effects of extracellular inhibitors by inactivating, evading, or overwhelming them (Figure 4).

\section{Inactivation of proteinase inhibitors}

Serpins can be cleaved and inactivated by MMPs (Desrochers and Weiss 1988; Desrochers et al 1991, 1992; Sires et al 1994; Gronski Jr et al 1997), NE (Cantin et al 1995), cathepsin B (Johnson and Travis 1977), and bacterial proteinases
(Sponer et al 1991). Serine proteinases cleave and inactivate TIMPs (Okada et al 1988). Proteolytic inactivation of $\alpha_{1}$-PI and TIMP-1 by MMP-12 and NE occurs in the cigarette smoke exposure model of emphysema in mice (Shapiro et al 2003).

ROS present in cigarette smoke or released by leukocytes activated by smoke inactivate $\alpha_{2}-\mathrm{M}$, and $\alpha_{1}$-PI, and SLPI in vitro by converting the methionine at the active sites of these inhibitors to methionine sulfoxide, which reduces their capacity to inhibit serine proteinases (Carp and Janoff 1979, 1980a, 1980b; Reddy et al 1994). Whether oxidative inactivation of proteinase inhibitors occurs in COPD patients is controversial, since some studies have detected oxidized $\alpha_{1}$-PI in lung samples from COPD patients but others have not (Gadek et al 1979; Stone et al 1983; Abboud et al 1985). Also, ROS can inactivate proteinases as outlined above. Global analysis of

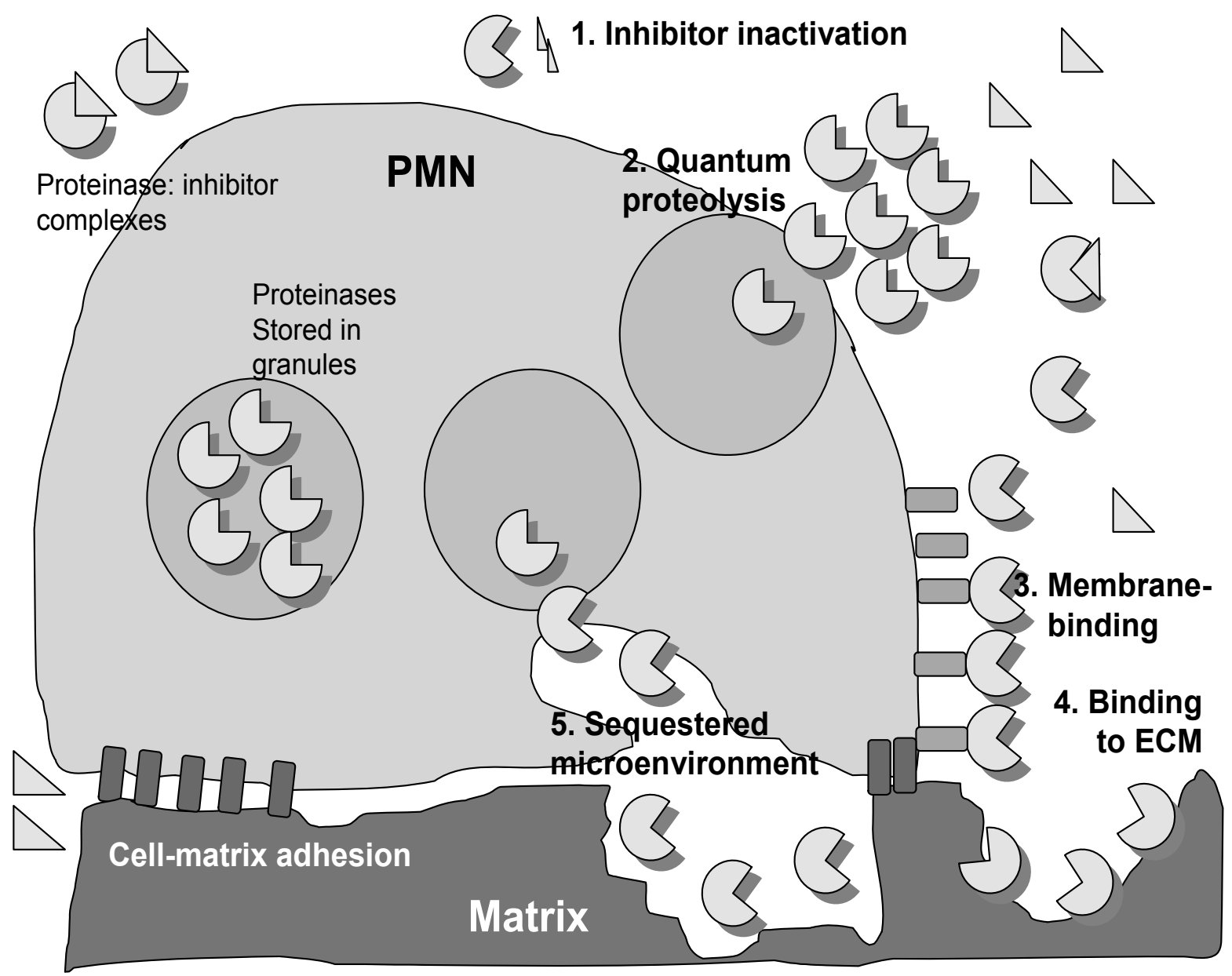

Figure 4 Mechanisms by which proteinases circumvent proteinase inhibitors in the extracellular space to cause lung injury in COPD. PMN store preformed proteinases within intracellular granules, and proteinases are released into the extracellular space when pro-inflammatory mediators induce PMN degranulation. Proteinases freely released by PMN are inhibited when they form complexes with extracellular inhibitors. However, proteinases can circumvent inhibitors by: I) cleaving or degrading inhibitors; 2) being released at very high concentrations into the extracellular space, thereby overwhelming inhibitors; 3 ) binding to cell membranes in inhibitor-resistant forms; 4) binding to matrix substrates in inhibitor-resistant forms; or 5) being released into sequestered microenvironments formed by tight adhesion of PMN to ECM into which diffusion of large inhibitors is impaired. 
the oxidation state of proteinase inhibitors in lung samples from COPD patients may not accurately reflect events in cellular microenvironments. ROS are short-lived molecules and are active only at short distances from the cells generating them before they are inactivated by antioxidants. It is likely that ROS and proteinases released into microenvironments around activated leukocytes act synergistically to locally inactivate inhibitors (or proteinases) and promote (or reduce) extracellular proteolysis.

\section{Evasion of inhibitors}

Proteinases can evade inhibitors by being released into sequestered microenvironments, binding tightly to substrates, or binding to cell surfaces (Figure 4).

\section{Sequestered microenvironments}

Integrin-mediated adhesion of inflammatory cells to matrix or to cells results in the formation of a "sealed" microenvironment, which prevents large inhibitors such as $\alpha_{1}$-PI (Campbell and Campbell 1988) and $\alpha_{2}-\mathrm{M}$ (Wright and Silverstein 1984) from penetrating into zones of contact between the cells and their substrates (Figure 4).

\section{Tight binding of proteinases to substrates}

$\mathrm{NE}$ binds very stably to elastin in an active form, and $\alpha_{1}$-PI and SLPI have reduced effectiveness against elastin-bound NE compared to soluble NE (Bruch and Bieth 1986; Morrison et al 1990, 1999). Since NE is bound to interstitial elastin in human emphysematous lungs (Damiano et al 1986), lung elastin-bound NE likely retains catalytic activity and contributes critically to destruction of elastin fibers in pulmonary emphysema (Figure 4). MMPs-1, -2 , and -9 bind to various ECM proteins, which may increase the retention, stability, and bioactivity of proteinases in the lung and facilitate their roles in extracellular proteolysis (Murphy et al 1992; Allan et al 1995).

\section{Membrane binding of proteinases}

MT-MMP and ADAMs are integral membrane proteinases, and some members of these families are resistant to inhibition by physiologic inhibitors. For example, ADAM-17 is resistant to inhibition by TIMPs-1 and -2 but not TIMP-3 (Amour et al 1998), and MT1-MMP is resistant to inhibition by TIMP-1 but not TIMP-2 (D'Ortho et al 1998). NE, CG, PR3, MMPs-8 and -9 (which lack transmembrane domains or glycosylphosphatidyl-inositol anchors) are also expressed on the surface of activated PMN (Owen et al 1995a, 1995b, 2003, 2004; Owen and Campbell 1998; Campbell et al 2000) (Figure 4). These surface-bound proteinases potently degrade lung ECM proteins and proteinase inhibitors and induce goblet cell degranulation (Takeyama et al 1998; Owen et al 1995b, 2003, 2004). However, unlike the soluble enzymes, the membrane-bound forms of these proteinases are resistant to inhibition by physiologic inhibitors (Owen et al 1995b, 2003, 2004; Owen and Campbell 1998; Campbell et al 2000). The inhibitor-resistance of membrane-bound NE is due to positive residues in NE binding to negatively charged sulfate groups in PMN plasma membrane proteoglycans (Campbell and Owen 2007), but the mechanism underlying the resistance of other cell-surface proteinases to inhibition is not known. Whatever the mechanism involved, catalytically active but inhibitor-resistant membrane-bound proteinases are well equipped to play critical roles in pathologies in COPD patients.

\section{Overwhelming of inhibitors}

Proteinases may overwhelm inhibitors when massive quantities of enzymes are released from large numbers of inflammatory cells, or when high concentrations of proteinases are released from individual cells (quantum proteolysis).

\section{Brisk influx of inflammatory cells}

During acute exacerbations of COPD, there is brisk influx of inflammatory cells into the airways. Active forms of NE, MMP-8, and MMP-9 released from these cells are detectable in lung secretions from COPD patients (Burnett et al 1987; Yoshioka et al 1995; Betsuyaku et al 1999; Hill et al 1999). Macrophage clearance of PMN recruited into the lung can be impaired in COPD patients by several mechanisms. First, cigarette smoke impairs expression of recognition molecules for apoptotic PMN on the macrophage surface (Hodge et al 2007). Second, NE cleaves recognition molecules for apoptotic PMN from the macrophage surface (Vandivier et al 2002). Third, when PMN ingest Hemophilus influenzae, which frequently colonizes the respiratory tract of COPD patients, PMN necrosis is rapidly induced (Naylor et al 2007). All of these processes hinder noninflammatory macrophage removal of PMN, instead promoting PMN necrosis and release of proteinases into the lung.

\section{Quantum proteolysis and PiZZ $\alpha_{1}$-PI deficiency}

$\mathrm{NE}$ is present at millimolar concentrations in each azurophil granule of PMN, which is more than 100-fold higher than the concentration of $\alpha_{1}$-PI in plasma (Liou and Campbell 1995). The release of an azurophil granule into the extracellular space is thus accompanied by a transient burst of proteolytic activity (Figure 4), which persists until the granule contents 
diffuse from this site, and the proteinase-inhibitor ratio falls below 1:1 (Liou and Campbell 1995). Individuals with severe, inherited deficiency of $\alpha_{1}$-PI have severe reductions in plasma levels of $\alpha_{1}$-PI (less than $4 \mu \mathrm{M}$ in PiZZ $\alpha_{1}$-PI deficient individuals versus $\sim 30 \mu \mathrm{M}$ in healthy PiMM individuals) due to loop sheet polymerization of $\mathrm{PiZ}$ mutant protein within hepatocytes, leading to reduced hepatocyte secretion of PiZ $\alpha_{1}$-PI (Lomas et al 1992). Quantum bursts of NE-mediated proteolytic activity associated with PMN migrating on ECM proteins are 10-fold larger in area and 4-fold longer in duration when PMN are bathed in serum from PiZZ patients compared to serum from healthy PiMM subjects (Campbell et al 1999), due to defective confinement of PMN-derived NE-mediated ECM degradation. Other mechanisms leading to excessive ECM destruction and lung inflammation in patients with severe, inherited deficiency of $\alpha_{1}$-PI include the formation of polymers of PiZ $\alpha_{1}$-PI mutant proteins in the lung, which not only are ineffective inhibitors of NE, but also have chemotactic activity for PMN (Mahadeva et al 2005; Lomas 2006).

\section{Potential for proteinase inhibition in COPD}

Based upon the available evidence, strategies to directly inhibit proteinases or to decrease the lung proteinase burden by decreasing inflammatory cell influx into the lung may be effective in limiting proteinase-induced lung injury in COPD patients.

\section{Direct proteinase inhibition}

\section{Supplementation with physiologic proteinase inhibitors}

This strategy is effective in murine models of COPD and in human subjects with COPD secondary to $\alpha_{1}$-PI deficiency. Delivering $\alpha_{1}$-PI systemically or by the inhaled route to smoke-exposed mice inhibits smoke-induced lung inflammation and airspace enlargement (Churg et al 2003b; Pemberton et al 2006). Alpha ${ }_{1}$-PI augmentation therapy is being used in the USA in $\alpha_{1}$-PI-deficient patients who have impaired lung function. Observational studies using this strategy confirm that it reduces bronchial inflammation, slows the rate of decline in lung function, increases quality-of-life scores, and decreases exacerbation frequency in $\alpha_{1}$-PI-deficient patients (Stockley et al 2002a; Juvelekian and Stoller 2004).

\section{Synthetic proteinase inhibitors}

Synthetic inhibitors have several advantages over physiologic inhibitors, including their resistance to oxidative and proteolytic inactivation and their effectiveness against both soluble and membrane-bound forms of proteinases (Owen et al 1995b, 2003, 2004). In animals exposed to cigarette smoke, or in transgenic mice over-expressing IL-13, delivering synthetic inhibitors of serine, metallo-, and cysteine proteinases by the systemic, oral, or inhaled routes blocks lung inflammation and airspace enlargement (Churg et al 2002; Lanone et al 2002; Stockley et al 2002b; Wright et al 2002; Pemberton et al 2005). Daily oral delivery of synthetic MMP inhibitors not only prevents airspace enlargement in mice chronically exposed to cigarette smoke, but also prevents progression of lung inflammation and airspace enlargement if therapy is initiated after emphysema has been established (Martin et al 2001). Synthetic inhibitors may also have potential in limiting the airflow obstruction produced by small airway fibrosis, since a synthetic compound that inhibits both MMP-9 and MMP-12 effectively blocks small airway fibrosis in cigarette smoke-exposed guinea pigs (Churg et al 2007a).

\section{Anti-inflammatory strategies}

Approaches to reducing inflammatory cell recruitment into the lung and activation of inflammatory cells would not only reduce the lung burden of inflammatory cell-derived proteinases but also that of other pathogenetic molecules generated by inflammatory cells in COPD patients such as ROS and pro-inflammatory mediators. Inhibitors of phosphodiesterase E4 (PDE4), the major PDE isoenzyme in inflammatory cells, decrease inflammatory cell migration, activation, and release of proteinases in vitro. Roflumilast (a PDE4 inhibitor) also protects mice from cigarette-smoke induced lung inflammation and airspace enlargement (Martorana et al 2005). Short-term clinical trials of phosphodiesterase E4 inhibitors in COPD patients have indicated that these inhibitors decrease lung inflammation, lung proteinases, and pro-inflammatory mediators, increase post bronchodilator forced expiratory volume in one second (Martina et al 2006; Calverley et al 2007; Grootendorst et al 2007), and reduce the frequency of acute exacerbations (Martina et al 2006; Calverley et al 2007). Statins (hydroxymethylglutaryl CoA reductase inhibitors) have diverse anti-inflammatory effects and also represent a potential new approach to COPD. This is supported by a recent study showing that simvastatin reduces lung inflammation, airspace enlargement, and pulmonary hypertension in cigarette smoke-exposed rats (Lee et al 2005). Several recent retrospective analyses have reported reduced morbidity and mortality in COPD patients 
taking statins for cardiovascular disease (Gueders et al 2005; Mancini et al 2006).

Other potential approaches to reduce inflammatory cell influx into the lung include anti-oxidant supplementation, inhibiting the transcription factor NF- $\kappa \mathrm{B}$, which drives the production of several pro-inflammatory molecules causing inflammation in COPD lungs (Retamales et al 2001; Szulakowski et al 2006) and inhibitors of chemokine receptors (Donnelly and Barnes 2006). Histone deacetylases, which are enzymes that switch off transcription of pro-inflammatory genes, are inactivated in COPD patients (Ito et al 2005) and represent another potential drug target in COPD patients.

\section{Conclusions and future directions}

There is now substantial evidence from animal model systems that proteinases make important contributions to pathologies in COPD and that proteinase inhibition and anti-inflammatory strategies effectively limit smoke-induced lung injury in mice. However, there are critical gaps in our knowledge about the roles of proteinases not only in pathogenesis of human COPD, but also in repair processes in the lung in COPD, and in lung biology in general.

It is important to note that murine model systems of COPD have limitations. Mice lack submucosal glands and do not develop mucus hypersecretion or acute exacerbations in the murine cigarette smoke exposure model. Mice also have fewer circulating PMN than humans and do not express MMP-1. The role of MMP-12 in human disease must be clarified. Early studies failed to detect increased expression of MMP-12 in lung samples (Finlay et al 1997; Imai et al 2001), but more recent studies using other techniques have demonstrated increased levels of MMP-12 in human COPD (Grumelli et al 2004; Molet et al 2005; Woodruff et al 2005; Demedts et al 2006). Thus, PMN-derived serine proteinases and MMPs in addition to MMP-12 may be important in human COPD. The challenge for the future will be to determine which proteinases play critical roles not only in airspace enlargement but also in airway pathologies in human COPD patients.

The biologic roles of proteinases expressed in the lung have also not been fully elucidated. Evidence is accumulating that some proteinases have both beneficial as well as deleterious roles in the murine lung. NE plays critical roles in bacterial killing in mice (Belaaouaj et al 1998), MMP-8 reduces lung inflammation (Owen et al 2004; Gueders et al 2005), and MMP12 has anti-tumor activities (Houghton et al 2006a). If these proteinases have similar beneficial activities in the human lung, this may limit the usefulness of inhibitors of these proteinases in COPD patients, who are at increased risk for developing respiratory tract infections and lung cancer (Skillrud et al 1986). Little is also known about repair processes in the COPD lung in general, or whether proteinases participate in lung repair in COPD. Studies of MMP-9 deficient mice in bleomycin-mediated lung injury suggest that MMP-9 might play roles in epithelial repair processes in the injured lung (Betsuyaku et al 2000a), and it is likely that other proteinases contribute to repair of the injured lung in COPD patients.

There have been no long-term clinical trials of synthetic proteinase inhibitors or anti-inflammatory agents in COPD patients due mainly to the high cost of such trials. In addition, we currently lack knowledge about appropriate biomarkers for studying the effectiveness of new treatment strategies in COPD patients. Nevertheless, based upon the evidence available, randomized clinical trails to test the safety and efficacy of proteinase inhibitors and anti-inflammatory agents are justified in COPD patients.

\section{Acknowledgments}

Dr Owen is supported by Public Health Services, NHLBI RO1 \# HL63137, NHLBI RO1 \# HL086814 and by a Clinical Innovator award from the Flight Attendants Medical Research Institute (FAMRI). There are no other conflicts of interest to report.

\section{Abbreviations}

ADAM, proteinase with a metalloproteinase and a disintegrin domain; $\alpha_{1}$-PI, $\alpha_{1}$-proteinase inhibitor; $\alpha_{1}$-Ach, $\alpha_{1}$-antichymotrypsin; $\alpha_{2}-\mathrm{M}, \alpha_{2}$-macroglobulin; CG, cathepsin $\mathrm{G}$; COPD, chronic obstructive pulmonary disease; ECM, extracellular matrix; EGFR, epithelial growth factor receptor; GRZ, granzyme; IGF, insulin like growth factor; IGFBP, insulin like growth factor binding protein; MMP, matrix metalloproteinase; MT-MMP, membrane-type MMP; NE, neutrophil elastase; MNP, mononuclear phagocyte; PAI, plasminogen activator inhibitor; PAR, proteinase activated receptor; PDE, phosphodiesterase; PMN, polymorphonuclear neutrophil; PR3, proteinase 3; ROS, reactive oxygen species; TGF, transforming growth factor; TIMP, tissue inhibitor of metalloproteinases; TNF- $\alpha$, tumor necrosis factor- $\alpha$; uPA, urokinase type plasminogen activator.

\section{References}

Abboud RT, Fera T, Richter A, et al. 1985. Acute effect of smoking on the functional activity of alpha $_{1}$-protease inhibitor in bronchoalveolar lavage fluid. ARRD, 131:79-85.

Abboud RT, Ofulue AF, Sansores RH, et al. 1998. Relationship of alveolar macrophage plasminogen activator and elastase activities to lung function and CT evidence of emphysema. Chest, 113:1257-63. 
Allan JA, Docherty AJP, Barker PJ, et al. 1995. Binding of gelatinases A and B to type- 1 collagen and other matrix components. Biochem J, 309:299-306.

Amitani R, Wilson R, Rutmen A, et al. 1991. Effects of human neutrophil elastase and Pseudomonas aeruginosa proteinases on human respiratory epithelium. Am J Respir Cell Mol Biol, 4:26-32.

Amour A, Slocombe PM, Webster A, et al. 1998. TNF-alpha converting enzyme (TACE) is inhibited by TIMP-3. FEBS Lett, 435:39-44.

Aoshiba K, Tamaoki J, Nagai A. 2001. Acute cigarette smoke exposure induces apoptosis of alveolar macrophages. Am J Physiol Lung Cell Mol Physiol, 2816:L1392-L1401.

Aoshiba K, Yokohori N, Nagai A. 2003. Alveolar wall apoptosis causes lung destruction and emphysematous changes. Am J Respir Cell Mol Biol, 285:555-62.

Balbin M, Fueyo A, Tester AM, et al. 2003. Loss of collagenase-2 confers increased skin tumor susceptibility to male mice. Nat Genet, 353:252-7.

Bedard M, McClure CD, Schiller NL, et al. 1993. Release of interleukin-8, interleukin-6, and colony-stimulating factors by upper airway epithelial cells: Implications for cystic fibrosis. Am J Respir Cell Mol Biol, 9:455-62.

Beeh KM, Beier J, Kornmann O, et al. 2003. Sputum matrix metalloproteinase-9, tissue inhibitor of metalloprotinease-1, and their molar ratio in patients with chronic obstructive pulmonary disease, idiopathic pulmonary fibrosis and healthy subjects. Respir Med, 976:634-9.

Belaaouaj A, McCarthy R, Baumann M, et al. 1998. Mice lacking neutrophil elastase reveal impaired host defense against gram negative bacterial sepsis. Nat Med, 4:615-8.

Betsuyaku T, Fukuda Y, Parks WC, et al. 2000a. Gelatinase B is required for alveolar bronchiolization after intratracheal bleomycin. $\mathrm{Am} \mathrm{J}$ Pathol, 157:525-35.

Betsuyaku T, Nishimura M, Takeyabu K, et al. 2000b. Decline in FEV(1) in community-based older volunteers with higher levels of neutrophil elastase in bronchoalveolar lavage fluid. Respiration, 673:261-7.

Betsuyaku T, Nishimura M, Takeyabu K, et al. 1999. Neutrophil granule proteins in bronchoalveolar lavage fluid from subjects with subclinical emphysema. Am J Respir Crit Care Med, 159:1985-91.

Betsuyaku T, Nishimura M, Yoshioka A, et al. 1996. [Neutrophil elastase and elastin-derived peptides in BAL fluid and emphysematous changes on CT scans]. Nihon Kyobu Shikkan Gakkai Zasshi, 34(Suppl):69-74.

Black RA. 2002. Tumor necrosis factor-alpha converting enzyme. Int $J$ Biochem Cell Biol, 341:1-5.

Black RA. 2004. TIMP3 checks inflammation. Nat Genet, 369:934-5.

Black RA, Rauch CT, Kozlosky CJ, et al. 1997. A metalloproteinase disintegrin that releases tumour-necrosis factor- $\alpha$ from cells. Nature, 385:729-33.

Bruch M, Bieth JG. 1986. Influence of elastin on the inhibition of leucocyte

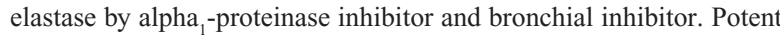
inhibition of elastin-bound elastase by bronchial inhibitor. Biochem $J$, 238:269-73.

Burnett D, Afford SC, Campbell EJ, et al. 1987. Characterization of elastase activity in bronchoalveolar lavage samples. ARRD, 135:A507.

Burns AR, Hosford SP, Dunn LA, et al. 1989. Respiratory epithelial permeability after cigarette smoke exposure in guinea pigs. J Appl Physiol, 665:2109-116.

Calverley PM, Sanchez-Toril F, McIvor A, et al. 2007. Effect of 1-year treatment with roflumilast in severe chronic obstructive pulmonary disease. Am J Respir Crit Care Med, 1762:154-61.

Campbell EJ, Campbell MA. 1988. Pericellular proteolysis by neutrophils in the presence of proteinase inhibitors: Effects of substrate opsonization. J Cell Biol, 106:667-76.

Campbell EJ, Campbell MA, Boukedes SS, et al. 1999. Quantum proteolysis by neutrophils: implications for pulmonary emphysema in alpha ${ }_{1}$ antitrypsin deficiency. $J C I, 104: 179-90$.
Campbell EJ, Campbell MA, Owen CA. 2000. Bioactive proteinase 3 on the cell surface of human neutrophils: quantification, catalytic activity, and susceptibility to inhibition. J Immunol, 165:3366-74.

Campbell EJ, Owen CA. 2007. The sulfate groups of chondroitin sulfate- and heparan sulfate-containing proteoglycans in neutrophil plasma membranes are novel binding sites for human leukocyte elastase and cathepsin G. J Biol Chem, 28219:14645-54.

Cantin A, Bilodeau G, Begin R. 1989. Granulocyte elastase-mediated proteolysis of alpha ${ }_{1}$-antitrypsin in cystic fibrosis bronchopulmonary secretions. Pediatr Pulmonol, 7:12-7.

Cao J, Rehemtulla A, Pavlaki M, et al. 2005. Furin directly cleaves proMMP-2 in the trans-Golgi network resulting in a nonfunctioning proteinase. J Biol Chem, 28012:10974-80.

Carp H, Janoff A. 1979. In vitro suppression of serum elastase-inhibitory capacity by reactive oxygen species generated by phagocytosing polymorphonuclear leukocytes. $J C I, 63: 793-7$.

Carp H, Janoff A. 1980a. Inactivation of bronchial mucous proteinase inhibitor by cigarette smoke and phagocyte-derived oxidants. Exp Lung Res, 1:225-37.

Carp H, Janoff A. 1980b. Potential mediator of inflammation: Phagocytederived oxidants suppress the elastase-inhibitory capacity of alpha ${ }_{1}^{-}$ proteinase inhibitor in vitro. $J C I, 66: 987-95$.

Carrell RW. 1986. Alpha-antitrypsin: Molecular pathology, leukocytes, and tissue damage. JCI, 78:1427-31.

Casalino-Matsuda SM, Monzon ME, Forteza RM. 2006. Epidermal growth factor receptor activation by epidermal growth factor mediates oxidantinduced goblet cell metaplasia in human airway epithelium. Am J Respir Cell Mol Biol, 345:581-91.

Cataldo D, Munaut C, Noel A, et al. 2000. MMP-2- and MMP-9-linked gelatinolytic activity in the sputum from patients with asthma and chronic obstructive pulmonary disease. Int Arch Allergy Immunol, 1233:259-67.

Chua F, Dunsmore SE, Clingen PH, et al. 2007. Mice lacking neutrophil elastase are resistant to bleomycin-induced pulmonary fibrosis. Am J Pathol, 1701:65-74.

Churg A, Tai H, Coulthard T, et al. 2006. Cigarette smoke drives small airway remodeling by induction of growth factors in the airway wall. Am J Respir Crit Care Med, 17412:1327-34.

Churg A, Wang R, Wang X, et al. 2007a. Effect of an MMP-9/MMP-12 inhibitor on smoke-induced emphysema and airway remodelling in guinea pigs. Thorax, 628:706-13.

Churg A, Wang RD, Tai H, et al. 2003a. Macrophage metalloelastase mediates acute cigarette smoke-induced inflammation via tumor necrosis factor-alpha release. Am J Respir Crit Care Med, 1678:1083-9.

Churg A, Wang RD, Xie C, et al. 2003b. alpha-1-Antitrypsin ameliorates cigarette smoke-induced emphysema in the mouse. Am J Respir Crit Care Med, 1682:199-207.

Churg A, Wang X, Wang RD, et al. 2007b. Alpha1-antitrypsin suppresses TNF-alpha and MMP-12 production by cigarette smoke-stimulated macrophages. Am J Respir Cell Mol Biol, 372:144-51.

Churg A, Zay K, Shay S, et al. 2002. Acute cigarette smoke-induced connective tissue breakdown requires both neutrophils and macrophage metalloelastase in mice. Am J Respir Cell Mol Biol, 273:368-74.

D'Armiento J, Dalal SS, Okada Y, et al. 1992. Collagenase expression in the lungs of transgenic mice causes pulmonary emphysema. Cell, 71:955-61.

D'Ortho MP, Stanton H, Butler M, et al. 1998. MT1-MMP on the cell surface causes focal degradation of gelatin films. FEBS Lett, 4212:159-64.

Damiano VV, Tsang A, Kucich U, et al. 1986. Immunolocalization of elastase in human emphysematous lungs. $J C I, 78: 482-93$.

Demedts IK, Morel-Montero A, Lebecque S, et al. 2006. Elevated MMP-12 protein levels in induced sputum from patients with COPD. Thorax, 613:196-201.

Deshmukh HS, Case LM, Wesselkamper SC, et al. 2005. Metalloproteinases mediate mucin $5 \mathrm{AC}$ expression by epidermal growth factor receptor activation. Am J Respir Crit Care Med, 1714:305-14. 
Desrochers PE, Jeffrey JJ, Weiss SJ. 1991. Interstitial collagenase (matrix metalloproteinase-1) expresses serpinase activity. JCI, 87:2258-65.

Desrochers PE, Mookhtiar K, Van Wart HE, et al. 1992. Proteolytic inactivation of alpha 1-proteinase inhibitor and alpha 1-antichymotrypsin by oxidatively activated human neutrophil metalloproteinases. $J$ Biol Chem, 267:5005-12.

Desrochers PE, Weiss SJ. 1988. Proteolytic inactivation of alpha-1-proteinase inhibitor by a neutrophil metalloproteinase. $J C I, 81: 1646-50$.

Di Stefano A, Turato G, Maestrelli P, et al. 1996. Airflow limitation in chronic bronchitis is associated with T-lymphocyte and macrophage infiltration of the bronchial mucosa. Am J Respir Crit Care Med, 1532:629-32.

Donnelly LE, Barnes PJ. 2006. Chemokine receptors as therapeutic targets in chronic obstructive pulmonary disease. Trends Pharmacol Sci, 2710:546-53.

Finlay GA, O’Driscoll L, Russell KJ, et al. 1997. Matrix metalloproteinase expression and production by alveolar macrophages in emphysema.. Am J Respir Crit Care Med, 156:240-7.

Foronjy RF, Mirochnitchenko O, Propokenko O, et al. 2006. Superoxide dismutase expression attenuates cigarette smoke- or elastase-generated emphysema in mice. Am J Respir Crit Care Med, 1736:623-31.

Fowlkes JL, Serra DM, Nagase H, et al. 1999. MMPs are IGFBP-degrading proteinases: implications for cell proliferation and tissue growth. Ann N Y Acad Sci, 878:696-9.

Fu X, Kassim SY, Parks WC, et al. 2001. Hypochlorous acid oxygenates the cysteine switch domain of pro-matrilysin (MMP-7). A mechanism for matrix metalloproteinase activation and atherosclerotic plaque rupture by myeloperoxidase. J Biol Chem, 27644:41279-87.

Fu X, Kassim SY, Parks WC, et al. 2003b. Hypochlorous acid generated by myeloperoxidase modifies adjacent tryptophan and glycine residues in the catalytic domain of matrix metalloproteinase-7 (matrilysin): an oxidative mechanism for restraining proteolytic activity during inflammation. J Biol Chem, 27831:28403-9.

Fu X, Kassim SY, Parks WC, et al. 2003a. Hypochlorous acid generated by myeloperoxidase modifies adjacent tryptophan and glycine residues in the catalytic domain of matrix metalloproteinase-7 (matrilysin): an oxidative mechanism for restraining proteolytic activity during inflammation. J Biol Chem, 27831:28403-9.

Gadek JE, Fells GA, Crystal RG. 1979. Cigarette smoking induces functional antiprotease deficiency in the lower respiratory tract of humans. Science, 206:1315-6.

Granelli-Peperno A, Vassalli J-D, Reich E. 1977. Secretion of plasminogen activator by human polymorphonuclear leukocytes. J Exp Med, 146:1693-706.

Gronski TJ Jr, Martin RL, Kobayashi DK, et al. 1997. Hydrolysis of a broad spectrum of extracellular matrix proteins by human macrophage elastase. J Biol Chem, 272:12189-94.

Grootendorst DC, Gauw SA, Verhoosel RM, et al. 2007. The PDE4 inhibitor roflumilast reduces sputum neutrophil and eosinophil numbers in patients with COPD. Thorax, 62:1081-7.

Gross P, Pfitzer EA, Tolker E, et al. 1965. Experimental emphysema. Its production with papain in normal and silicotic rats. Arch Environ Health, 11:50-8.

Grumelli S, Corry DB, Song LZ, et al. 2004. An immune basis for lung parenchymal destruction in chronic obstructive pulmonary disease and emphysema. PLoS Med, 11:e8.

Gueders MM, Balbin M, Rocks N, et al. 2005. Matrix metalloproteinase-8 deficiency promotes granulocytic allergen-induced airway inflammation. J Immunol, 1754:2589-97.

Hautamaki RD, Kobayashi DK, Senior RM, et al. 1997. Requirement for macrophage elastase for cigarette smoke-induced emphysema in mice. Science, 277:2002-4.

Henskens YMC, Veerman ECI, Nieuw Amerongen AVN. 1996. Cystatins in health and disease. Biol Chem Hoppe-Seyler, 377:71-86.

Hill AT, Bayley D, Stockley RA. 1999. The interrelationship of sputum inflammatory markers in patients with chronic bronchitis. Am J Respir Crit Care Med, 1603:893-8.
Hodge S, Hodge G, Ahern J, et al. 2007. Smoking alters alveolar macrophage recognition and phagocytic ability: Implications in COPD. Am J Respir Cell Mol Biol, 37:748-55.

Hodge S, Hodge G, Holmes M, et al. 2005. Increased airway epithelial and $\mathrm{T}$-cell apoptosis in COPD remains despite smoking cessation. Eur Respir J, 253:447-54.

Hodge S, Hodge G, Nairn J, et al. 2006. Increased airway granzyme b and perforin in current and ex-smoking COPD subjects. COPD, 34:179-87.

Hogg JC, Chu F, Utokaparch S, et al. 2004. The nature of small-airway obstruction in chronic obstructive pulmonary disease. $N$ Engl J Med, 35026:2645-53

Houghton AM, Grisolano JL, Baumann ML, et al. 2006a. Macrophage elastase (matrix metalloproteinase-12) suppresses growth of lung metastases. Cancer Res, 6612:6149-55.

Houghton AM, Quintero PA, Perkins DL, et al. 2006b. Elastin fragments drive disease progression in a murine model of emphysema. J Clin Invest, 1163:753-9.

Hubbard RC, Fells G, Gadek J, et al. 1991. Neutrophil accumulation in the lung in $\alpha 1$-antitrypsin deficiency. Spontaneous release of leukotriene $\mathrm{B}_{4}$ by alveolar macrophages. $J C I, 88: 891-7$.

Hunninghake GW, Davidson JM, Rennard S, et al. 1981. Elastin fragments attract macrophage precursors to diseased sites in pulmonary emphysema. Science, 212:925-7.

Imai K, Dalal SS, Chen ES, et al. 2001. Human collagenase (matrix metalloproteinase-1) expression in the lungs of patients with emphysema. Am J Respir Crit Care Med, 1633 Pt 1:786-91.

Imai K, Ohuchi E, Aoki T, et al. 1996. Membrane-type matrix metalloproteinase 1 is a gelatinolytic enzyme and is secreted in a complex with tissue inhibitor of metalloproteinases 2. Cancer Res, 5612:2707-10.

Ito K, Ito M, Elliott WM, et al. 2005. Decreased histone deacetylase activity in chronic obstructive pulmonary disease. $N$ Engl $\mathrm{J} \mathrm{Med}$, 35219:1967-76

Johnson D, Travis J. 1977. Inactivation of human $\alpha_{1}$ proteinase inhibitor by thiol proteinases. Biochem J, 163:639-41.

Juvelekian GS, Stoller JK. 2004. Augmentation therapy for alpha(1)antitrypsin deficiency. Drugs, 6416:1743-56.

Kang MJ, Homer RJ, Gallo A, et al. 2007. IL-18 is induced and IL-18 receptor alpha plays a critical role in the pathogenesis of cigarette smoke-induced pulmonary emphysema and inflammation. J Immunol, 1783:1948-59.

Kang MJ, Oh YM, Lee JC, et al. 2003. Lung matrix metalloproteinase-9 correlates with cigarette smoking and obstruction of airflow. J Korean Med Sci, 186:821-7.

Kao RC, Wehner NG, Skubitz KM, et al. 1988. Proteinase 3. A distinct human polymorphonuclear leukocyte proteinase that produces emphysema in hamsters. $J C I, 82: 1963-73$.

Karlinsky J, Fredette J, Davidovits G, et al. 1983. The balance of lung connective tissue elements in elastase-induced emphysema. J Lab Clin Med, 1022:151-62.

Kasahara Y, Tuder, RM, Cool CD, et al. 2001. Endothelial cell death and decreased expression of vascular endothelial growth factor and vascular endothelial growth factor receptor 2 in emphysema. Am J Respir Crit Care Med, 1633 Pt 1:737-44.

Kasahara Y, Tuder RM, Taraseviciene-Stewart L, et al. 2000. Inhibition of VEGF receptors causes lung cell apoptosis and emphysema. J Clin Invest, 10611:1311-9.

Kassim SY, Fu X, Liles WC, et al. 2005. NADPH oxidase restrains the matrix metalloproteinase activity of macrophages. $J$ Biol Chem, 28034:30201-5.

Kohri K, Ueki IF, Nadel JA. 2002. Neutrophil elastase induces mucin production by ligand-dependent epidermal growth factor receptor activation. Am J Physiol Lung Cell Mol Physiol, 2833:L531-L40.

Lanone S, Zheng T, Zhu Z, et al. 2002. Overlapping and enzyme-specific contributions of matrix metalloproteinases- 9 and -12 in IL-13-induced inflammation and remodeling. J Clin Invest, 1104:463-74. 
Laurell C-B, Eriksson S. 1963. The electrophoretic alpha-1-globulin pattern of serum in alpha-1-antitrypsin deficiency. Scand J Clin Lab Invest, $15: 132-40$

Lee JH, Lee DS, Kim EK, et al. 2005. Simvastatin inhibits cigarette smoking-induced emphysema and pulmonary hypertension in rat lungs. Am J Respir Crit Care Med, 1728:987-93.

Li XY, Rahman I, Donaldson K, et al. 1996. Mechanisms of cigarette smoke induced increased airspace permeability. Thorax, 515:465-71.

Liou TG, Campbell EJ. 1995. Non-isotropic enzyme-inhibitor interactions: A novel non-oxidative mechanism for quantum proteolysis by human neutrophils. Biochemistry, 34:16171-7.

Lomas DA. 2006. Parker B. Francis lectureship. Antitrypsin deficiency, the serpinopathies, and chronic obstructive pulmonary disease. Proc Am Thorac Soc, 36:499-501.

Lomas DA, Evans DL, Finch JT, et al. 1992. The mechanism of Z alpha 1-antitrypsin accumulation in the liver. Nature, 3576379:605-7.

Maeno T, Houghton AM, Quintero PA, et al. 2007. CD8+ T Cells are required for inflammation and destruction in cigarette smoke-induced emphysema in mice. J Immunol, 17812:8090-6.

Mahadeva R, Atkinson C, Li Z, et al. 2005. Polymers of Z alpha1-antitrypsin co-localize with neutrophils in emphysematous alveoli and are chemotactic in vivo. Am J Pathol, 1662:377-86.

Mancini GB, Etminan M, Zhang B, et al. 2006. Reduction of morbidity and mortality by statins, angiotensin-converting enzyme inhibitors, and angiotensin receptor blockers in patients with chronic obstructive pulmonary disease. J Am Coll Cardiol, 4712:2554-60.

Martin RL, Shapiro SD, Tong SE, et al. 2001. Macrophage Metalloelastase Inhibitors. In: Hansel TBP, ed. New Drugs for Asthma, Allergy and COPD. Basel Karger: Prog Respir Res, pp. 177-80.

Martina SD, Ismail MS, Vesta KS. 2006. Cilomilast: orally active selective phosphodiesterase-4 inhibitor for treatment of chronic obstructive pulmonary disease. Ann Pharmacother, 4010:1822-8.

Martorana PA, Beume R, Lucattelli M, et al. 2005. Roflumilast fully prevents emphysema in mice chronically exposed to cigarette smoke Am J Respir Crit Care Med, 1727:848-53.

Mason RW, Johnson DA, Barrett AJ, et al. 1986. Elastinolytic activity of human cathepsin L. Biochem J, 233:925-7.

Mohan S, Thompson GR, Amaar YG, et al. 2002. ADAM-9 is an insulinlike growth factor binding protein-5 protease produced and secreted by human osteoblasts. Biochemistry, 4151:15394-403.

Molet S, Belleguic C, Lena H, et al. 2005. Increase in macrophage elastase (MMP-12) in lungs from patients with chronic obstructive pulmonary disease. Inflamm Res, 541:31-6.

Morrison HM, Welgus HG, Owen CA, et al. 1999. Interaction between leukocyte elastase and elastin: quantitative and catalytic analyses. Biochim Biophys Acta, 1430:179-90.

Morrison HM, Welgus HG, Stockley RA, et al. 1990. Inhibition of human leukocyte elastase bound to elastin: Relative ineffectiveness and two mechanisms of inhibitory activity. Am J Respir Cell Mol Biol, 2:263-9.

Murphy G, Allan JA, Willenbrock F, et al. 1992. The role of the C-terminal domain in collagenase and stromelysin specificity. $J$ Biol Chem, 267:9612-8.

Murphy G, Docherty AJP. 1992. The matrix metalloproteinases and their inhibitors. Am J Respir Cell Mol Biol, 7:120-5.

Murphy G, Stanton H, Cowell S, et al. 1999. Mechanisms for pro matrix metalloproteinase activation. APMIS, 1071:38-44.

Naylor EJ, Bakstad D, Biffen M, et al. 2007. Haemophilus influenzae induces neutrophil necrosis: a role in chronic obstructive pulmonary disease? Am J Respir Cell Mol Biol, 372:135-43.

Ning W, Dong Y, Sun J, et al. 2007. Cigarette smoke stimulates matrix metalloproteinase-2 activity via EGR-1 in human lung fibroblasts. Am J Respir Cell Mol Biol, 364:480-90.

Okada Y, Watanabe S, Nakanishi I, et al. 1988. Inactivation of tissue inhibitor of metalloproteinases by neutrophil elastase and other serine proteinases. FEBS-Lett, 229:157-60.

Owen CA. 2005. Proteinases and oxidants as targets in the treatment of chronic obstructive pulmonary disease. Proc Am Thorac Soc, 24:373-85.
Owen CA, Campbell EJ. 1998. Angiotensin II generation at the cell surface of activated neutrophils: Novel cathepsin G-mediated catalytic activity that is resistant to inhibition. $J$ Immunol, 160:1436-43.

Owen CA, Campbell EJ. 1999. The cell biology of leukocyte-mediated proteolysis. J Leukoc Biol, 65:137-50.

Owen CA, Campbell MA, Boukedes SS, et al. 1995a. Inducible binding of cathepsin $\mathrm{G}$ to the cell surface of neutrophils: A mechanism for mediating extracellular proteolytic activity of cathepsin G. J Immunol, 155:5803-10.

Owen CA, Campbell MA, Boukedes SS, et al. 1994. A discrete subpopulation of human monocytes expresses a neutrophil-like pro-inflammatory (P) phenotype. Am J Physiol (Lung Cell Mol Physiol 11), 267, p. L775-L785.

Owen CA, Campbell MA, Sannes PL, et al. 1995b. Cell-surface-bound elastase and cathepsin $\mathrm{G}$ on human neutrophils. A novel, non-oxidative mechanism by which neutrophils focus and preserve catalytic activity of serine proteinases. $J$ Cell Biol, 131:775-89.

Owen CA, Hu Z, Barrick B, et al. 2003. Inducible expression of tissue inhibitor of metalloproteinases-resistant matrix metalloproteinase-9 on the cell surface of neutrophils. Am J Resp Cell Mol Biol, 29:283-94.

Owen CA, Hu Z, Lopez-Otin C, et al. 2004. Membrane-bound matrix metalloproteinase- 8 on activated polymorphonuclear cells is a potent, tissue inhibitor of metalloproteinase-resistant collagenase and serpinase. J Immunol, 17212:7791-803.

Pemberton PA, Cantwell JS, Kim KM, et al. 2005. An inhaled matrix metalloprotease inhibitor prevents cigarette smoke-induced emphysema in the mouse. COPD, 23:303-10.

Pemberton PA, Kobayashi D, Wilk BJ, et al. 2006. Inhaled recombinant alpha 1-antitrypsin ameliorates cigarette smoke-induced emphysema in the mouse. COPD, 32:101-8.

Primakoff P, Myles DG. 2000. The ADAM gene family: surface proteins with adhesion and protease activity. Trends Genet, 162:83-7.

Rahman I, MacNee W. 1996. Role of oxidants/antioxidants in smokinginduced lung diseases. Free Radic Biol Med, 215:669-81.

Rajavashisth TB, Xu XP, Jovinge S, et al. 1999. Membrane type 1 matrix metalloproteinase expression in human atherosclerotic plaques: evidence for activation by proinflammatory mediators. Circulation, 9924:3103-9.

Raza SL, Nehring LC, Shapiro SD, et al. 2000. Proteinase activated receptor1 regulation of macrophage elastase secretion by serine proteinases. $J$ Biol Chem, 52:41243-50.

Reddy VY, Desrochers PE, Pizzo SV, et al. 1994. Oxidative dissociation of human alpha 2-macroglobulin tetramers into dysfunctional dimers. J Biol Chem, 269:4683-91.

Reilly JJ, Chapman HA Jr. 1988. Association between alveolar macrophage plasminogen activator activity and indices of lung function in young cigarette smokers. ARRD, 1386:1422-8.

Retamales I, Elliott WM, Meshi B, et al. 2001. Ampification of inflammation in emphysema and its association with latent adenoviral infection. Am J Respir Crit Care Med, 164:469-73.

Saetta M. 1999. Airway inflammation in chronic obstructive pulmonary disease. Am J Respir Crit Care Med, 1605(Pt 2)S17-S20.

Saksela O, Rifkin DB. 1988. Cell-associated plasminogen activation: Regulation and physiological functions. Ann Rev Cell Biol, 4:93-126.

Sato H, Takino T, Okada Y, et al. 1994. A matrix metalloproteinase expressed on the surface of invasive tumour cells. Nature, 370:61-5.

Senior RM, Griffin GL, Mecham RP. 1980. Chemotactic activity of elastinderived peptides. J Clin Invest, 664:859-62.

Senior RM, Tegner H, Kuhn C III, et al. 1977. The induction of pulmonary emphysema with human leukocyte elastase. ARRD, 116:469-75.

Shao MX, Nakanaga T, Nadel JA. 2004. Cigarette smoke induces MUC5AC mucin overproduction via tumor necrosis factor-alpha-converting enzyme in human airway epithelial (NCI-H292) cells. Am J Physiol Lung Cell Mol Physiol, 2872:L420-L27.

Shapiro SD, Campbell EJ, Senior RM, et al. 1991. Proteinases secreted by human mononuclear phagocytes. J Rheumatol, 27:95-8. 
Shapiro SD, Goldstein NM, Houghton AM, et al. 2003. Neutrophil elastase contributes to cigarette smoke-induced emphysema in mice. Am J Pathol, 1636:2329-35.

Shi G-P, Munger JS, Meara JP, et al. 1992. Molecular cloning and expression of human alveolar macrophage cathepsin S, an elastinolytic cysteine protease. J Biol Chem, 267:7258-62.

Sires UI, Murphy G, Welgus HG, et al. 1994. Matrilysin is much more efficient than other metalloproteinases in the proteolytic inactivation of alpha 1-antitrypsin. Biochem Biophys Res Commun, 204:613-20.

Skillrud DM, Offord KP, Miller RD. 1986. Higher risk of lung cancer in chronic obstructive pulmonary disease. A prospective, matched, controlled study. Ann Intern Med, 1054:503-7.

Smallman LA, Hill SL, Stockley RA. 1984. Reduction of ciliary beat frequency in vitro by sputum from patients with bronchiectasis: A serine proteinase effect. Thorax, 39:663-7.

Smyth MJ, O'Connor MD, Trapani JA. 1996. Granzymes: a variety of serine protease specificities encoded by genetically distinct subfamilies. J Leukoc Biol, 605:555-62.

Sommerhoff CP, Nadel JA, Basbaum CB, et al. 1990. Neutrophil elastase and cathespin $\mathrm{G}$ stimulate secretion from cultured bovine airway gland serous cells. $J C I, 85: 862-9$.

Sponer M, Nick H-P, Schnebli H-P. 1991. Different susceptibility of elastase inhibitors to inactivation by proteinases from Staphylococcus aureus and Pseudomonas aeruginosa. Biol Chem Hoppe-Seyler, 372:963-70.

Stockley RA, Bayley DL, Unsal I, et al. 2002a. The effect of augmentation therapy on bronchial inflammation in alpha1-antitrypsin deficiency. Am J Respir Crit Care Med, 16511:1494-8.

Stockley RA, Bayley DL, Unsal I, et al. 2002b. The effect of augmentation therapy on bronchial inflammation in alpha1-antitrypsin deficiency. Am J Respir Crit Care Med, 16511:1494-8.

Stone PJ, Calore, JD, McGowan, SE, et al. 1983. Functional alpha-1protease inhibitor in the lower respiratory tract of cigarette smokers is not decreased. Science, 221:1187-9.

Szulakowski P, Crowther AJ, Jimenez LA, et al. 2006. The effect of smoking on the transcriptional regulation of lung inflammation in patients with chronic obstructive pulmonary disease. Am J Respir Crit Care Med, 1741:41-50

Taipale J, Koli K, Keski-Oja J. 1992. Release of transforming growth factorbeta 1 from the pericellular matrix of cultured fibroblasts and fibrosarcoma cells by plasmin and thrombin. $J$ Biol Chem, 26735:25378-84.

Takeyama K, Agusti C, Ueki I, et al. 1998. Neutrophil-dependent goblet cell degranulation: role of membrane-bound elastase and adhesion molecules. Am J Physiol, 275, p. L294-L302.
Takino TH, Sato H, Shinagawa A, et al. 1995. Identification of the second membrane-type matrix metalloproteinase (MT-MMP-2) gene from a human placenta cDNA library. MT-MMPs form a unique membranetype subclass in the MMP family.. J Biol Chem, 270:23013-20.

Turato G, Zuin R, Saetta M. 2001. Pathogenesis and pathology of COPD. Respiration, 682:117-28.

Van Den Steen PE, Proost P, Wuyts A, et al. 2000. Neutrophil gelatinase B potentiates interleukin- 8 tenfold by aminoterminal processing, whereas it degrades CTAP-III, PF-4, and GRO- $\alpha$ and leaves RANTES and MCP-2 intact. Blood, 96:2673-81.

Vandivier RW, Fadok VA, Hoffmann PR, et al. 2002. Elastase-mediated phosphatidylserine receptor cleavage impairs apoptotic cell clearance in cystic fibrosis and bronchiectasis. J Clin Invest, 1095:661-70.

Vassalli J-D, Sappino AP, Belin D. 1991. The plasminogen activator/plasmin system. JCI, 88:1067-72.

Wang Z, Zheng T, Zhu Z, et al. 2000. Interferon gamma induction of pulmonary emphysema in the adult murine lung. J Exp Med, 19211:1587-600.

Woessner JF Jr. 1991. Matrix metalloproteinases and their inhibitors in connective tissue remodeling. FASEB J, 5:2145-54.

Woodruff PG, Koth LL, Yang YH, et al. 2005. A distinctive alveolar macrophage activation state induced by cigarette smoking. Am J Respir Crit Care Med, 17211:1383-92.

Wright JL, Farmer SG, Churg A. 2002. Synthetic serine elastase inhibitor reduces cigarette smoke-induced emphysema in guinea pigs. Am J Respir Crit Care Med, 1667:954-60.

Wright SD, Silverstein SC. 1984. Phagocytosing macrophages exclude proteins from zones of contact with targets. Nature, 309:359-61.

Wu K, Urano T, Ihara H, et al. 1995. The cleavage and inactivation of plasminogen activator inhibitor type 1 by neutrophil elastase: the evaluation of its physiologic relevance in fibrinolysis. Blood, 86:1056-61.

Yoshioka A, Betsuyaku T, Nishimura M, et al. 1995. Excessive neutrophil elastase in bronchoalveolar lavage fluid in subclinical emphysema. Am J Respir Crit Care Med, 1526(Pt 1):2127-32.

Yu Q, Stamenkovic I. 2000. Cell surface-localized matrix metalloproteinase-9 proteolytically activates TGF-beta and promotes tumor invasion and angiogenesis. Genes Dev, 142:163-76.

Zheng T, Kang MJ, Crothers K, et al. 2005. Role of cathepsin S-dependent epithelial cell apoptosis in IFN-gamma-induced alveolar remodeling and pulmonary emphysema. J Immunol, 17412:8106-15.

Zheng T, Zhu Z, Wang Z, et al. 2000. Inducible targeting of IL-13 to the adult lung causes matrix metalloproteinase- and cathepsin-dependent emphysema. J Clin Invest, 1069:1081-93. 